\title{
Antihyperthermic treatment decreases perihematomal hypodensity
}

Pablo Hervella, PhD, Manuel Rodríguez-Yáñez, MD, PhD, José Manuel Pumar, MD, PhD, Paulo Ávila-Gómez, BSc, Andrés da Silva-Candal, PhD, Ignacio López-Loureiro, PhD, Elena Rodríguez-Maqueda, BSc, Clara Correa-Paz, PhD, José Castillo, MD, PhD, Tomás Sobrino, PhD, Francisco Campos, PhD, and Ramón Iglesias-Rey, PhD

Neurology ${ }^{\circledR}$ 2020;94:e1738-1748. doi:10.1212/WNL.0000000000009288

\section{Abstract}

\section{Objective}

To investigate the effect on perihematomal hypodensity and outcome of a decrease in body temperature in the first 24 hours in patients with intracerebral hemorrhage (ICH).

\section{Methods}

In this retrospective study on a prospectively registered database, among the 1,100 patients, 795 met all the inclusion criteria. Temperature variations in the first 24 hours and perihematomal hypodensity (PHHD) were recorded. Patients $\geq 37.5^{\circ} \mathrm{C}$ were treated with antihyperthermic drugs for at least 48 hours. The main objective was to determine the association among temperature variation, PHHD, and outcome at 3 months.

\section{Results}

The decrease in temperature in the first 24 hours increased the possibility of good outcome 11-fold. Temperature decrease, lower PHHD volume, and a good outcome were observed in $31.8 \%$ of the patients who received antihyperthermic treatment.

\section{Conclusion}

The administration of early antihyperthermic treatment in patients with spontaneous ICH with a basal axillary temperature $\geq 37.5^{\circ} \mathrm{C}$ resulted in good outcome in a third of the treated patients.

\author{
Correspondence \\ Dr. Hervella \\ pablo.hervella.lorenzo@ \\ sergas.es \\ or Dr. Iglesias-Rey \\ ramon.iglesias.rey@ \\ sergas.es
}

\section{RELATED ARTICLE}

\section{Editorial}

Hyperthermia, cerebral edema, and outcome in intracerebral hemorrhage: Too darn hot

Page 687

From the Clinical Neurosciences Research Laboratory (LINC) (P.H., P.Á.-G., A.d.S.-C., I.L.-L., E.R.-M., C.-C.P., J.C., T.S., F.C., R.I.-R.), Health Research Institute of Santiago de Compostela (IDIS); and Stroke Unit, Department of Neurology (M.R.-Y.), and Department of Neuroradiology (J.M.P.), Hospital Clínico Universitario, Santiago de Compostela, Spain.

Go to Neurology.org/N for full disclosures. Funding information and disclosures deemed relevant by the authors, if any, are provided at the end of the article. 


\section{Glossary}

ANOVA $=$ analysis of variance; $\mathbf{C I}=$ confidence interval; $\mathbf{I C H}=$ intracerebral hemorrhage; $\mathbf{m R S}=$ modified Rankin Scale; NIHSS = NIH Stroke Scale; OR = odds ratio; PHHD = perihematomal hypodensity.

Spontaneous (nontraumatic) intracerebral hemorrhage (ICH) constitutes around $10 \%-15 \%$ of strokes and is associated with poor outcome. ${ }^{1}$ In the last decade, mortality due to ICH has decreased but, unlike ischemic stroke, both morbidity and dependence are increasing, probably due to the absence of effective treatments and to population aging., ${ }^{2,3}$

ICH growth during the first hours is a critical factor for neurologic deterioration and poor outcome, regardless of other factors that determine high mortality and poor outcome at the time of ICH, such as hematoma volume and intracranial hypertension with displacement of intracerebral structures. ${ }^{4,5}$ The relation between ICH growth in the first hours and poor outcome was recently confirmed in an extensive meta-analysis. ${ }^{6}$

Clinical trials aimed at halting hematoma growth have failed to show efficacy so far ${ }^{7}$ and new therapeutic targets are being sought, now focusing on other secondary mechanisms associated with brain damage, such as the perihematomal hypodensity (PHHD) volume. ${ }^{8-10}$

Hyperthermia has been associated with poor outcome in $\mathrm{ICH}^{11}$ and with the increase of PHHD volume, ${ }^{12}$ especially by hypertensive mechanisms. ${ }^{13}$ Hypothermia has been proposed as a treatment for ICH that is associated with a decrease in PHHD. However, this kind of treatment is not recommended for patients with $\mathrm{ICH}$ due to the high morbidity and mortality, and more clinical trials are needed to verify its efficacy and safety. ${ }^{14-17}$

We analyzed the association between the clinical outcome at 3 months and the decrease in body temperature in the first 24 hours in patients with ICH. Then, we analyzed the association between the PHHD and the decrease in temperature, and finally tested the hypothesis of treating patients with $\mathrm{ICH}$ with antihyperthermic drugs for reducing PHHD and improving the clinical outcome.

\section{Methods}

\section{Study design}

This is a retrospective study performed on a prospective register of patients in a databank approved by the Galician Ethics Committee. Patients were treated in the emergency service of a single tertiary university hospital (University Clinical Hospital of Santiago de Compostela [Spain]) by trained health personnel and later admitted to the stroke unit and treated by neurologists specialized in cerebrovascular treatment according to a protocol based on Spanish and international clinical guidelines. ${ }^{18,19}$

\section{Standard protocol approvals, registrations, and patient consents}

This study was carried out in accordance with the Helsinki Declaration of the World Medical Association (2008) and approved by the Clinical Research Ethics Committee of Galicia. Informed consent was obtained from patients or their relatives at the time of inclusion in the registry, authorizing the anonymous use of data for further studies.

\section{Inclusion and exclusion criteria}

From January 2008 to December 2018, 1,100 patients with spontaneous ICH were included in the data bank. Exclusion criteria were the following: (1) latency time (from the onset of symptoms to hospital care $)>24$ hours $(\mathrm{n}=185)$; (2) previous modified Rankin Scale (mRS) score >1 ( $\mathrm{n}=193)$; (3) known chronic inflammatory diseases $(n=26)$; (4) absence of at least 2 neuroimaging studies in the first week $(\mathrm{n}=208)$; $(5)$ isolated primary intraventricular hemorrhage $(\mathrm{n}=23)$; (6) loss of followup (face-to-face or telephone) for 3 months $(\mathrm{n}=174)$; (7) patients undergoing surgical removal of hematoma $(n=38)$. For the purpose of this study, 795 patients were considered valid.

\section{Clinical and analytical variables}

The variables analyzed in this study are shown in table 1 and table-e1 (doi.org/10.5061/dryad.np5hqbzps). In particular, axillary temperature was recorded upon admission and every 6 hours during the whole hospitalization time in the stroke unit. For this study, we used the maximum temperature obtained in the first 24 hours after admission to the stroke unit. As the main variable, we determined the difference between the axillary temperature at admission and the temperature at 24 hours (differences $>0^{\circ} \mathrm{C}$ considered as increase and $\leq 0^{\circ} \mathrm{C}$ as decrease).

The intensity of the neurologic deficit was determined by the NIH Stroke Scale (NIHSS) upon admission and every 6 hours during the hospitalization in the stroke unit. For this study, the NIHSS was assessed at admission. The functional deficit was assessed by the mRS score at discharge and at 3 months \pm 15 days. Both scales were evaluated by internationally certified neurologists, supervised by the same neurologist (M.R.-Y.).

\section{Neuroimaging studies}

All of the patients included in the study underwent at least 2 computerized CT scans: the first one on admission and the next one during the first 7 days. The volumes were determined using the $\mathrm{ABC} / 2$ method $^{20}$ until 2016 and afterwards through the automated planimetric method. ${ }^{21}$ The PHHD volume was calculated by subtracting the hematoma volume from the total volume of the lesion (figure 1). ICH growth and PHHD volume were categorized as $\leq 6 \mathrm{~mL}$ vs $>6$ 
Table 1 Clinical variables, biochemical measures, and neuroimaging values by outcome groups at 3 months

\begin{tabular}{|c|c|c|c|}
\hline & $\begin{array}{l}\text { Good } \\
\text { outcome } \\
(n=348)\end{array}$ & $\begin{array}{l}\text { Poor } \\
\text { outcome } \\
(n=447)\end{array}$ & $p$ Value \\
\hline Age, y & $71.1 \pm 12.8$ & $76.9 \pm 11.6$ & $<0.0001$ \\
\hline Women & 41.7 & 45.9 & 0.250 \\
\hline Latency time, min & $242.7 \pm 207.8$ & $231.7 \pm 204.7$ & 0.489 \\
\hline $\begin{array}{l}\text { Previous modified Rankin } \\
\text { Scale score }\end{array}$ & $0(0,1)$ & $1(0,1)$ & $<0.0001$ \\
\hline Arterial hypertension & 66.7 & 66.4 & 0.504 \\
\hline Diabetes & 19.3 & 23.3 & 0.192 \\
\hline Smoking & 13.5 & 7.8 & 0.010 \\
\hline Alcoholism & 16.1 & 14.5 & 0.952 \\
\hline Dyslipidemia & 42.5 & 36.5 & 0.092 \\
\hline Ischemic heart disease & 8.3 & 10.7 & 0.278 \\
\hline Atrial fibrillation & 15.8 & 25.1 & 0.002 \\
\hline Heart failure & 2.9 & 4.0 & 0.441 \\
\hline Previous stroke & 17.3 & 18.8 & 0.514 \\
\hline $\begin{array}{l}\text { Axillary temperature at } \\
\text { admission, }{ }^{\circ} \mathrm{C}\end{array}$ & $36.5 \pm 0.7$ & $36.3 \pm 0.9$ & $<0.0001$ \\
\hline $\begin{array}{l}\text { Temperature at admission } \\
- \text { at } 24 \text { hours, }{ }^{\circ} \mathrm{C}\end{array}$ & $0.48 \pm 0.32$ & $0.01 \pm 0.38$ & $<0.0001$ \\
\hline $\begin{array}{l}\text { Decrease in temperature } \\
\text { in } 24 \text { hours }\end{array}$ & 96.2 & 54.8 & $<0.0001$ \\
\hline $\begin{array}{l}\text { Antihyperthermic } \\
\text { treatment }\end{array}$ & 13.5 & 22.6 & 0.001 \\
\hline Basal glycemia, mg/dL & $130.0 \pm 45.4$ & $146.6 \pm 50.2$ & $<0.0001$ \\
\hline Leukocytes, $\times 10^{3} / \mathrm{mL}$ & $7.1 \pm 2.7$ & $12.3 \pm 6.8$ & 0.001 \\
\hline Platelets, $\times 10^{3} / \mathrm{mL}$ & $216.6 \pm 83.7$ & $191.2 \pm 88.0$ & 0.685 \\
\hline Fibrinogen, mg/dL & $425.2 \pm 90.1$ & $453.3 \pm 110.1$ & 0.001 \\
\hline C-reactive protein, $\mathrm{mg} / \mathrm{L}$ & $4.3 \pm 4.4$ & $6.1 \pm 5.8$ & $<0.0001$ \\
\hline $\begin{array}{l}\text { Glycosylated } \\
\text { hemoglobin, \% }\end{array}$ & $5.9 \pm 0.8$ & $5.9 \pm 0.8$ & 0.148 \\
\hline LDL cholesterol, mg/dL & $115.2 \pm 24.0$ & $100.2 \pm 23.9$ & 0.105 \\
\hline HDL cholesterol, mg/dL & $43.1 \pm 14.4$ & $39.1 \pm 18.7$ & 0.734 \\
\hline Triglycerides, mg/dL & $102.7 \pm 36.9$ & $98.4 \pm 49.0$ & 0.806 \\
\hline $\begin{array}{l}\text { Microalbuminuria, } \\
\mathrm{mg} / 24 \mathrm{~h}\end{array}$ & $18.8 \pm 35.1$ & $22.3 \pm 33.6$ & 0.403 \\
\hline Sedimentation rate, $\mathrm{mm}$ & $29.1 \pm 19.9$ & $43.8 \pm 31.6$ & 0.004 \\
\hline $\begin{array}{l}\mathrm{ICH} \text { volume at } \\
\text { admission, } \mathrm{mL}\end{array}$ & $20.9 \pm 18.7$ & $46.4 \pm 40.9$ & $<0.0001$ \\
\hline Growth of the ICH, $\mathrm{mL}$ & $12.1 \pm 24.0$ & $21.9 \pm 35.6$ & $<0.0001$ \\
\hline Growth of the ICH $\geq 6 \mathrm{~mL}$ & 23.6 & 46.8 & $<0.0001$ \\
\hline PHHD volume, mL & $7.6 \pm 10.6$ & $17.8 \pm 21.7$ & $<0.0001$ \\
\hline
\end{tabular}

Table 1 Clinical variables, biochemical measures, and neuroimaging values by outcome groups at 3 months (continued)

\begin{tabular}{|c|c|c|c|}
\hline & $\begin{array}{l}\text { Good } \\
\text { outcome } \\
(n=348)\end{array}$ & $\begin{array}{l}\text { Poor } \\
\text { outcome } \\
(n=447)\end{array}$ & $p$ Value \\
\hline PHHD volume $\geq 6 \mathrm{~mL}$ & 27.9 & 62.6 & $<0.0001$ \\
\hline Leukoaraiosis & 31.9 & 44.5 & $<0.0001$ \\
\hline NIHSS at admission & $9(5,13)$ & $15(11,19)$ & $<0.0001$ \\
\hline $\begin{array}{l}\text { Modified Rankin Scale } \\
\text { score at } 3 \text { months }\end{array}$ & $2(0,2)$ & $5(3,6)$ & $<0.0001$ \\
\hline ICH topography & & & 0.133 \\
\hline Deep hemisphere & 54.3 & 46.8 & \\
\hline Lobar & 38.8 & 45.2 & \\
\hline Cerebellar & 4.9 & 4.0 & \\
\hline Brainstem & 2.1 & 4.0 & \\
\hline $\begin{array}{l}\text { Hemorrhagic } \\
\text { contamination }\end{array}$ & 14.9 & 25.3 & $<0.0001$ \\
\hline ICH diagnosis & & & 0.071 \\
\hline Hypertensive & 51.4 & 45.0 & \\
\hline Amyloid & 10.9 & 16.1 & \\
\hline Anticoagulants & 12.4 & 21.5 & \\
\hline Other/indeterminate & 25.3 & 17.4 & \\
\hline
\end{tabular}

Abbreviations: $\mathrm{HDL}=$ high-density lipoprotein; $\mathrm{ICH}=$ intracerebral hemorrhage; LDL = low-density lipoprotein; NIHSS = NIH Stroke Scale; PHHD = perihematomal hypodensity.

Values are mean \pm SD or $\%$.

$\mathrm{mL}$ due to its sensitivity and specificity according to the literature. ${ }^{6,22}$ All neuroimaging studies were reviewed by the same neuroradiologist (J.M.P.).

\section{Intervention}

Following the hospital protocol, all patients with a baseline temperature $\geq 37.5^{\circ} \mathrm{C}$ were treated with $1 \mathrm{~g}$ of paracetamol orally or $2 \mathrm{~g}$ of metamizole intravenously every 8 hours. The treatment was maintained for at least 48 hours, regardless of the recorded temperature. We considered a positive response to antihyperthermic treatment when the maximum temperature in the first 24 hours was lower than the temperature at admission. Patients were not subjected to other hypothermic procedures.

\section{Outcome endpoints}

The main objective of the study was to determine the association between the temperature decrease in the first 24 hours and the clinical outcome at 3 months (mRS categorized: $\leq 2$ good outcome vs $>2$ poor outcome). Secondary objectives were (1) the association between the PHHD volume and the outcome at 3 months and (2) the influence of the antihyperthermic treatment on the PHHD volume and its repercussion on the outcome at 3 months. 
Figure 1 Example of CT scan

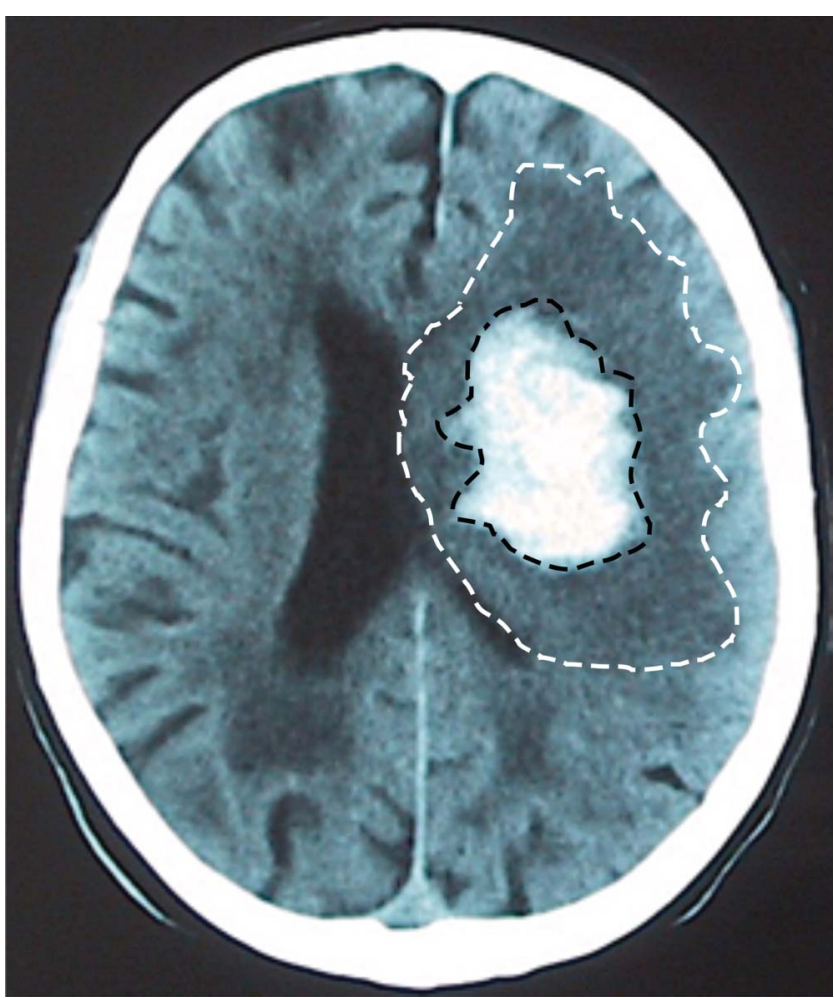

CT scan obtained during the first week after admission. The perihematomal hypodensity volume is calculated by subtracting the hematoma volume (region inside the black dashes) from the total volume of the lesion (white dashes).

\section{Statistical method}

First, an analysis was performed describing the sample. Frequencies and percentages were calculated for categorical variables, while the continuous variables were expressed by mean values \pm SD or median values and interquartile range depending on their adjustment to normality. KolmogorovSmirnov test with Lilliefors correction was applied to assess normality. Analysis of variance (ANOVA) and $\chi^{2}$ tests were performed to determine differences in the variables between the groups (patients with good outcome vs patients with poor outcome). Bivariate correlations were performed using Spearman coefficients. The logistic regression analysis was performed with the independent variables selected by their statistical significance in the bivariate analysis or by their clinical significance. These results were shown as odd ratios (ORs) with $95 \%$ confidence intervals (CIs). A $p$ value $<0.05$ was considered to be statistically significant. All statistical analyses were conducted in SPSS 21.0 (IBM, Armonk, NY).

\section{Data availability}

All data are available within the text of the article. Further anonymized data could be made available to qualified investigators upon reasonable request.

\section{Results}

In this study, 795 patients with ICH were included and 305 were excluded. Some differences were found between the included and excluded groups. The included patients were older and more hypertensive and hyperlipemic, with more atrial fibrillation and higher basal temperature. Regarding the ICH diagnosis, there were more amyloid and anticoagulant cases and less indeterminate and primary intraventricular hemorrhages in the included group $(7.5 \%$ vs $0 \% ; p<0.0001)$. The rest of the variables studied that could be determined in the excluded group were similar in the 2 groups. A description of the clinical and analytical variables of the included patients is provided in table e-1 (doi.org/10. 5061/dryad.np5hqbzps).

\section{Main objective: the effect of temperature decrease on the outcome at 3 months}

An analysis was carried out to study the variables that influence the outcome at 3 months. At 3 months ( \pm 15 days), 348 patients $(43.8 \%)$ presented good outcome while 447 (52.2\%) showed poor outcome. The variables associated with the outcome are listed in table 1 . Regarding body temperature, it can be seen that the temperature at admission was higher in patients with good outcome $\left(36.5 \pm 0.7^{\circ} \mathrm{C}\right.$ vs $36.3 \pm$ $\left.0.9^{\circ} \mathrm{C} ; p<0.0001\right)$, although in both groups the average temperature was below $37^{\circ} \mathrm{C}$. However, the decrease in temperature in the first 24 hours was significantly higher in patients with good outcome ( $0.48 \pm 0.32$ vs $0.01 \pm 0.38$; $p<$ 0.0001 ) and the percentage of patients with temperature decrease was also higher in the good outcome group (96.2\% vs $54.8 \%$; $p$ 0.0001). In addition, we observed a relationship (ANOVA test; $p<0.0001$ ) between variations in axillary temperature in the first 24 hours and the mRS values, with the patients with high temperature decrease being the ones with lower mRS (figure 2).

In the logistic regression model (table 2), the temperature decrease in the first 24 hours was independently associated with good outcome at 3 months (adjusted OR, 11.28; 95\% CI, $4.69-27.01 ; p<0.0001)$. Therefore, the decrease in temperature in the first 24 hours multiplies by 11 the possibility of good outcome, while the hematoma growth multiplies by 5 the possibility of poor outcome (adjusted OR, 5.55; 95\% CI, $2.63-11.11 ; p<0.0001)$.

\section{Secondary objectives}

Influence of PHHD volume on the outcome at 3 months The average PHHD volume measured in the second CT neuroimage was $13.3 \pm 18.20 \mathrm{~mL}$ in the whole sample; 373 patients presented a PHHD volume $\geq 6 \mathrm{~mL}$ and 418 patients $<6 \mathrm{~mL}$. PHHD volume was directly related to worse mRS scores at 3 months (figure 3 ). A descriptive analysis (table e-2; doi.org/10.5061/dryad.np5hqbzps) categorizing the patients according to the PHHD volume showed that good outcome is more frequent in the group of patients with 


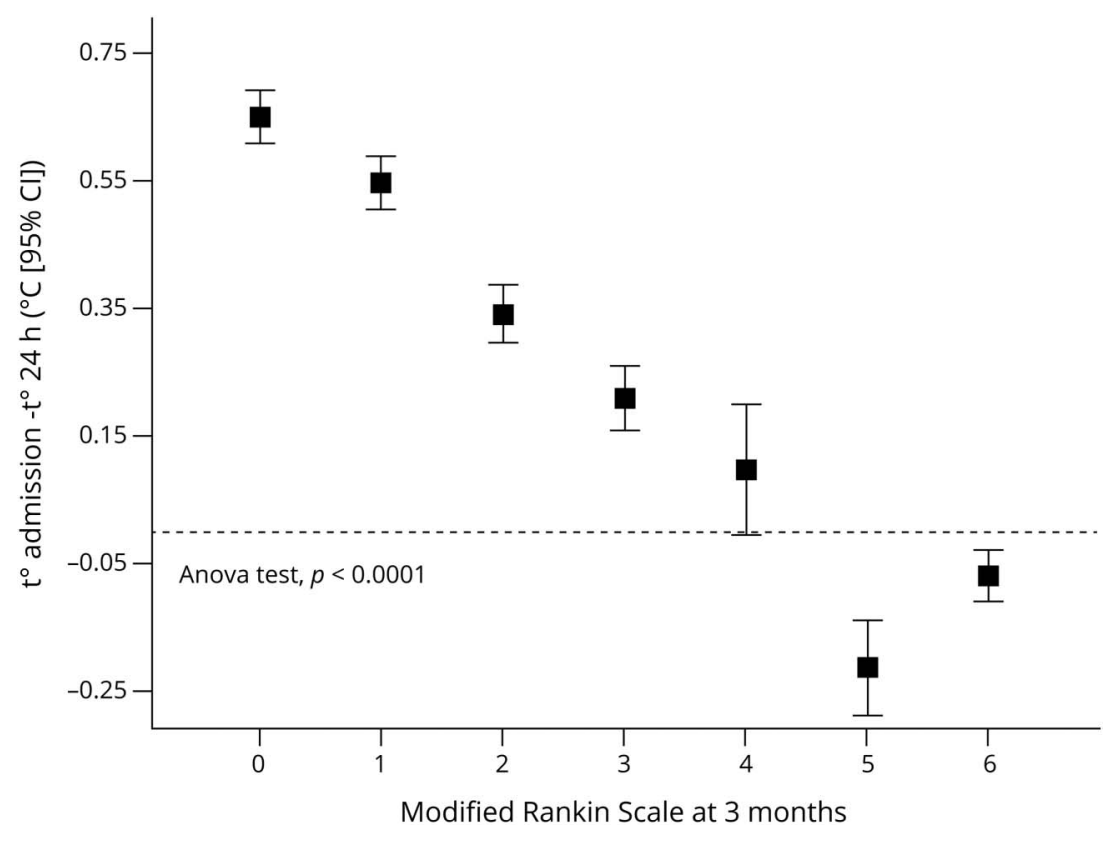

Decrease in temperature during the first 24 hours in relation to the mRS score at 3 months \pm 15 days. $\mathrm{Cl}=$ confidence interval. a PHHD volume $<6 \mathrm{~mL}$ (72.1\% vs $27.9 \% ; p<0.0001)$. Age, frequency of arterial hypertension, temperature at admission, leukocytes, fibrinogen, microalbuminuria, C-reactive protein, and sedimentation rate showed lower values in patients with a PHHD volume $<6 \mathrm{~mL}$. The ICH volume and the NIHSS at admission also showed lower values in patients with $\mathrm{PHHD}<6 \mathrm{~mL}$.

The logistic regression analysis (table 2) showed that good outcome is 0.23 times more frequent in patients with a PHHD volume $\geq 6 \mathrm{~mL}$ (OR, 0.23; 95\% CI, 0.17-0.31; $p<0.0001$ ), although we did not observe an association between outcome and $\mathrm{PHHD}$ volume after adjusting with $\mathrm{ICH}$ growth.

Regarding temperature, PHHD volume was lower in patients with a decrease in temperature in the first 24 hours (figure 4). The temperature decrease in the first 24 hours was more frequent in patients with a $\mathrm{PHHD}$ volume $<6 \mathrm{~mL}$ (91.6\% vs $64.2 \% ; p<0.0001)$. In another adjusted logistic regression model (table e-3; doi.org/10.5061/dryad.np5hqbzps), the decrease in temperature was found to be 17 times more frequent in patients with a PHHD volume $<6 \mathrm{~mL}$ (adjusted OR, 16.87; 95\% CI, 3.75-75.84; $p<0.0001)$.

\section{Influence of the antihyperthermic treatment on PHHD volume and its repercussion on the outcome at 3 months}

Among the 795 patients included in the study, 148 received antihyperthermic treatment according to the hospital protocol (their clinical and biological variables are listed in table 3 ). Body temperature was reduced in 65 patients (43.9\%), while in $83(56.1 \%)$ the treatment did not cause a reduction of the temperature. Interestingly, among the 647 patients who did not receive treatment, 529 showed a decrease in body temperature $(84.6 \%)$.

The average decrease in temperature was significantly different in the 3 groups of patients: responders, nonresponders, and not treated with antihyperthermic drugs $\left(0.86 \pm 0.45^{\circ} \mathrm{C}\right.$ vs $-0.09 \pm 0.25^{\circ} \mathrm{C}$ vs $0.21 \pm 0.39^{\circ} \mathrm{C} ; p<0.0001$ ) (figure $5 \mathrm{~A}$ ); likewise, $\mathrm{PHHD}$ volume was lower in the group of patients with a positive response to treatment compared with patients who responded negatively and those with no treatment $(1.9 \pm$ $2.8 \mathrm{~mL}$ vs $36.6 \pm 23.4 \mathrm{~mL}$ vs $11.2 \pm 15.8 \mathrm{~mL} ; p<0.0001)$ (figure 5B).

A good outcome at 3 months was observed in $72.3 \%$ of responder patients to antihyperthermic drugs, while none of the patients with a negative response experienced good outcome at 3 months ( $p<0.0001$ ) (table e-4; doi.org/10.5061/dryad.np5hqbzps). The positive response to antihyperthermic treatment was also associated with good outcome as shown in the logistic regression analysis of table 2 (OR, 3.00; 95\% CI, 1.71-5.28; $p<0.0001$; adjusted OR, 1.67; 95\% CI, 1.18-7.87; $p=0.022$ ).

\section{Discussion}

Spontaneous ICH constitutes a progressive cause of mortality and morbidity that until now could be considered a therapeutically orphan disease. Neither the surgical approach nor procoagulant drugs has shown safety or efficacy. ${ }^{7,23-25}$ Thus new therapeutic approaches have been explored focusing on more reachable objectives. In 
Table 2 Multivariate analysis

\begin{tabular}{|c|c|c|c|c|c|c|}
\hline Independent variables & OR not adjusted & $95 \% \mathrm{Cl}$ & $p$ Value & OR adjusted & $95 \% \mathrm{Cl}$ & $p$ Value \\
\hline Decrease in temperature in $\mathbf{2 4}$ hours & 20.78 & $12.78-33.77$ & $<0.0001$ & 11.28 & $4.69-27.01$ & $<0.0001$ \\
\hline PHHD volume $\geq 6 \mathrm{~mL}^{\mathrm{a}}$ & 0.23 & $0.17-0.31$ & $<0.0001$ & 0.61 & $0.37-1.02$ & 0.058 \\
\hline Positive antihyperthermic treatment & 3.00 & $1.71-5.28$ & $<0.0001$ & 1.67 & $1.18-7.87$ & 0.022 \\
\hline Growth of the ICH $\geq 6 \mathrm{~mL}$ & 0.35 & $0.26-0.48$ & $<0.0001$ & 0.18 & $0.09-0.38$ & $<0.0001$ \\
\hline NIHSS at admission & 0.79 & $0.76-0.81$ & $<0.0001$ & 0.83 & $0.78-0.87$ & $<0.0001$ \\
\hline Age & 0.96 & $0.95-0.97$ & $<0.0001$ & 0.97 & $0.94-0.99$ & 0.007 \\
\hline Glycemia & 0.99 & $0.99-0.99$ & $<0.0001$ & 0.99 & $0.98-0.99$ & 0.028 \\
\hline Axillary temperature at admission & 0.58 & $0.49-0.68$ & $<0.0001$ & 1.14 & $0.80-1.62$ & 0.464 \\
\hline ICH volume at admission & 0.96 & $0.94-0.97$ & $<0.0001$ & 0.99 & $0.98-1.00$ & 0.143 \\
\hline Previous modified Rankin Scale score & 0.66 & $0.57-0.77$ & $<0.0001$ & 0.72 & $0.50-1.04$ & 0.080 \\
\hline Smoking & 1.61 & $1.10-2.37$ & 0.014 & 1.27 & $0.54-3.03$ & 0.583 \\
\hline Atrial fibrillation & 0.51 & $0.37-0.71$ & $<0.0001$ & 0.82 & $0.43-1.532$ & 0.527 \\
\hline Leukocytes & 0.94 & $0.90-0.97$ & 0.001 & 0.98 & $0.89-1.07$ & 0.621 \\
\hline Fibrinogen & 0.99 & $0.99-0.99$ & $<0.0001$ & 0.99 & $0.99-1.00$ & 0.063 \\
\hline C-reactive protein & 0.93 & $0.90-0.95$ & $<0.0001$ & 1.01 & $0.95-1.08$ & 0.704 \\
\hline Sedimentation rate & 0.99 & $0.98-0.99$ & $<0.0001$ & 0.99 & $0.98-1.01$ & 0.732 \\
\hline Leukoaraiosis & 0.58 & $0.45-0.75$ & $<0.0001$ & 0.80 & $0.39-1.63$ & 0.545 \\
\hline Hemorrhagic contamination & 0.44 & $0.33-0.61$ & $<0.0001$ & 0.63 & $0.35-1.14$ & 0.124 \\
\hline
\end{tabular}

Abbreviations: $\mathrm{Cl}=$ confidence interval; $\mathrm{ICH}=$ intracerebral hemorrhage; NIHSS = NIH Stroke Scale; $\mathrm{OR}=$ odds ratio; $\mathrm{PHHD}=$ perihematomal hypodensity. Dependent variable: good outcome at 3 months \pm 15 days.

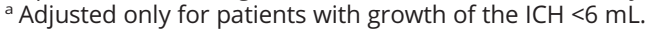

recent years, PHHD has been identified as an attractive possibility.

PHHD mechanisms are complex and not completely understood, and therefore we prefer to use the descriptive name perihematomal hypodensity instead of perihematomal edema, frequently cited in the literature. Undoubtedly, many events of a large PHHD are associated with inflammatory mechanisms ${ }^{26}$ and have been linked to the appearance of a cytotoxic edema in the first hours and with a vasogenic edema in later phases. ${ }^{9,27,28}$ However, other mechanisms should not be ruled out, such as ischemic necrosis or neurotoxicity associated with coagulation mechanisms. ${ }^{29,30}$ A novel and promising hypothesis associated the presence and progression of PHHD with the existence of spreading depressions and isoelectric spreading depolarizations, although its association with episodes of metabolic derangement and ischemic lesions remains speculative. ${ }^{31}$ It has also been postulated that upregulated microRNA-23a-3p in patients with ICH promotes the apoptosis of cerebral vascular endothelial cells by downregulating ZO-1, thus participating in the formation of PHHD after ICH. ${ }^{32}$

The prognostic role of PHHD in ICH has been widely debated in the literature, with contradictory results. ${ }^{10}$ The latest prospective studies showed a strong relationship between PHHD volume and higher mortality and morbidity. ${ }^{8,9,33-36}$ This prognostic capacity is higher during the first 24 hours, progressively decreasing its value during the subacute phase of $\mathrm{ICH}^{9}{ }^{9}$ Although the prognostic capacity of the PHHD volume over the clinical outcome was not the main objective of our study, we initially showed that PHHD volume was significantly higher in patients with a worse outcome at 3 months, and a PHHD volume $<6 \mathrm{~mL}$ was 4 times more frequent in patients with a good outcome. However, the association between PHHD and clinical outcome was not observed after including other relevant variables in the model, such as ICH volume and temperature. Moreover, high levels of significant prognostic factors of poor outcome at 3 months (such as fibrinogen or temperature) were also found in patients with low volumes of PHHD, pointing out the weak association between PHHD and clinical outcome.

PHHD has been the target of different treatments for $\mathrm{ICH}^{15,16}$ Corticosteroids could be effective in late phases in which vasogenic edema may predominate, however, they have not shown utility and cause a greater number of complications. ${ }^{37}$ Similarly, hypertonic solutions did not affect the outcome at 3 months. ${ }^{38}$ 


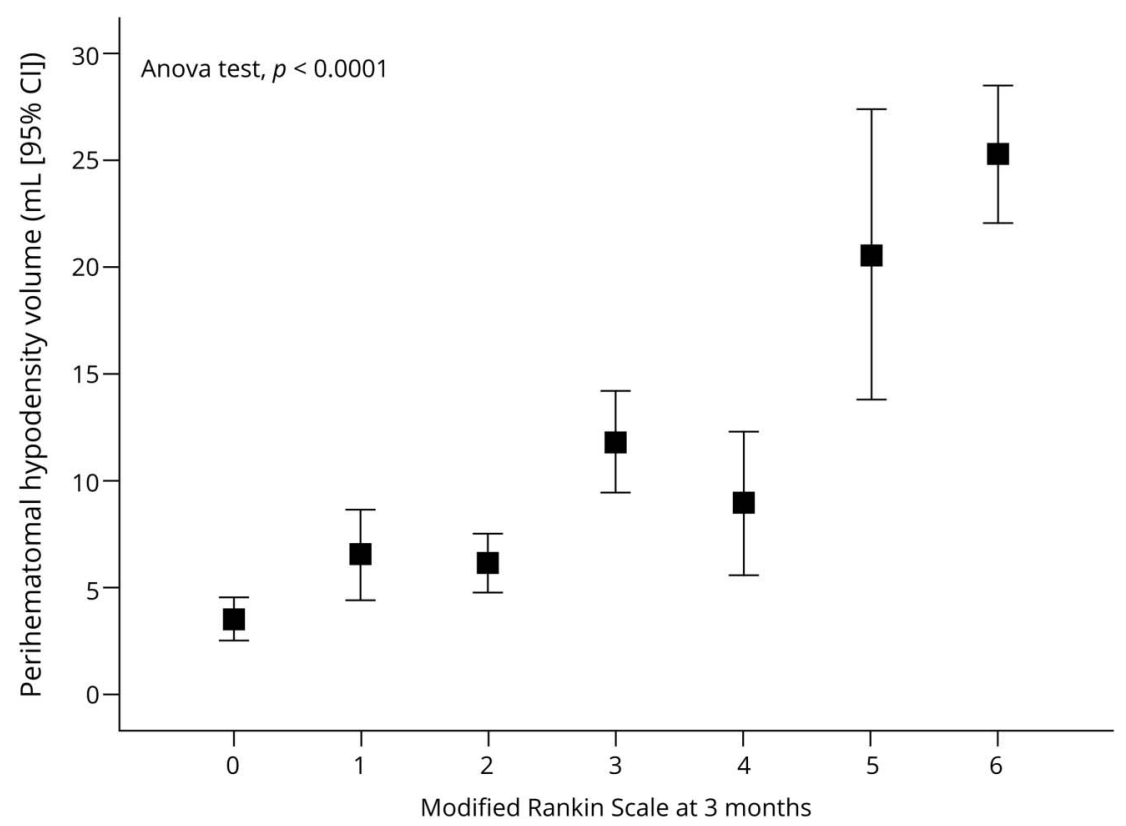

PHHD volume in each score of the $m R S$ evaluated at 3 months \pm 15 days. ANOVA = analysis of variance; $\mathrm{Cl}=$ confidence interval.
There is a clear relation between hyperthermia, even moderate, and a poor outcome of nontraumatic $\mathrm{ICH} .{ }^{11,39-42}$ In our experience, an axillary temperature at admission $\geq 37.5^{\circ} \mathrm{C}$ multiplies by 4 the risk of a poor outcome at 3 months. ${ }^{11}$ Preclinical trials aiming for hypothermic temperatures of $35^{\circ} \mathrm{C}$ confirmed the association between hypothermia and a decrease in PHHD along with a better outcome, ${ }^{17}$ with evidence that supports the translationality to human clinical practice, ${ }^{43-45}$ especially if hypothermia is established early. ${ }^{14}$ However, this therapeutic procedure is

Figure 4 Perihematomal hypodensity (PHHD) volume

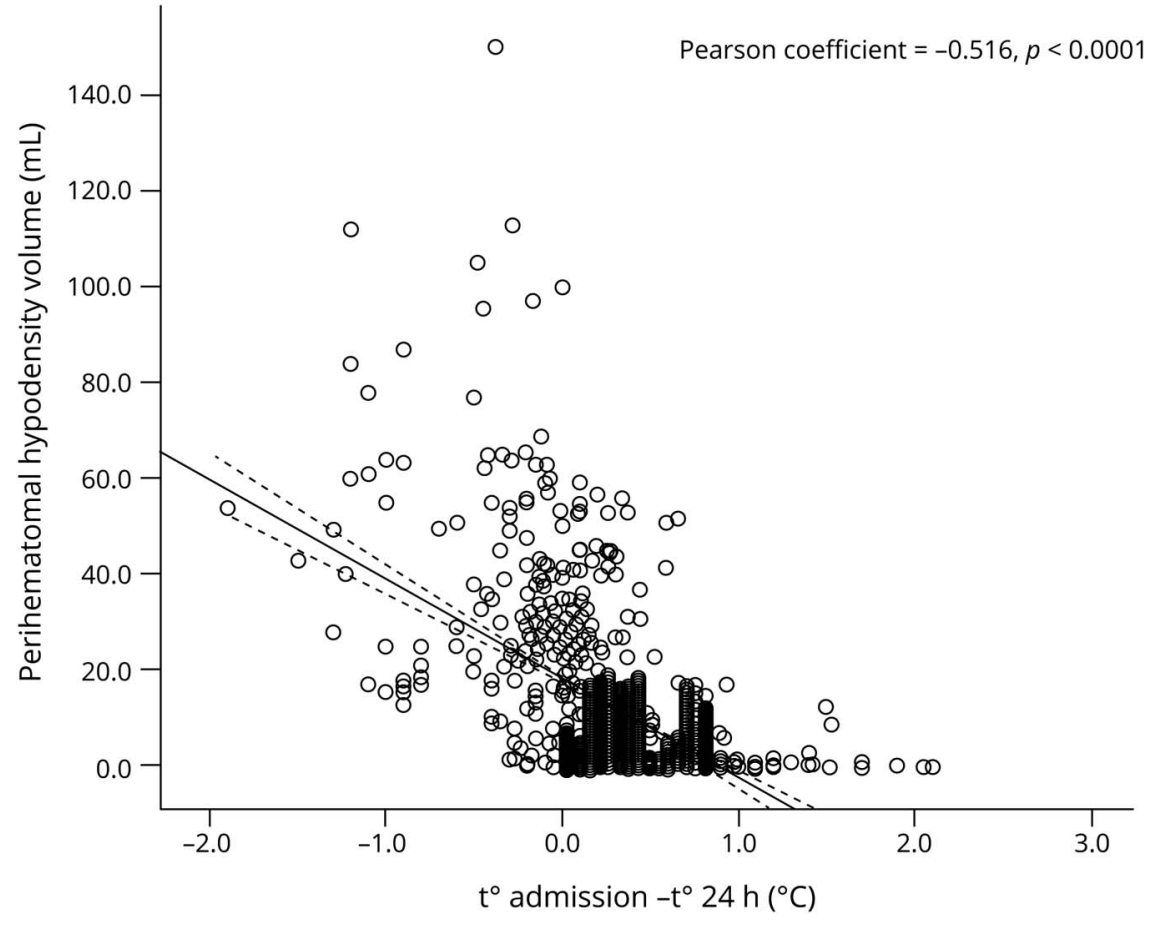

Scatterplot of decrease in body temperature at 24 hours and the PHHD volume. The decrease in temperature is associated with a lower PHHD volume. 
Table 3 Clinical variables, biochemical measures, and neuroimaging values categorized in patients with a negative and positive response to antihyperthermic treatment

\begin{tabular}{|c|c|c|c|}
\hline & \multicolumn{2}{|c|}{$\begin{array}{l}\text { Antihyperthermic } \\
\text { treatment }\end{array}$} & \multirow[b]{2}{*}{$p$ Value } \\
\hline & No $(n=647)$ & Yes $(n=148)$ & \\
\hline Age, y & $73.3 \pm 13.1$ & $73.6 \pm 13.4$ & 0.738 \\
\hline Women & 44.4 & 38.0 & 0.146 \\
\hline Latency time, min & $\begin{array}{l}231.7 \pm \\
208.9\end{array}$ & $227.7 \pm 187.6$ & 0.840 \\
\hline $\begin{array}{l}\text { Previous modified Rankin } \\
\text { Scale score }\end{array}$ & $1(0,1)$ & $1(0,1)$ & 0.599 \\
\hline Arterial hypertension & 58.0 & 77.3 & $<0.0001$ \\
\hline Diabetes & 19.1 & 27.6 & 0.015 \\
\hline Smoking & 10.6 & 11.7 & 0.681 \\
\hline Alcoholism & 14.5 & 20.2 & 0.077 \\
\hline Dyslipidemia & 36.1 & 40.5 & 0.291 \\
\hline Ischemic heart disease & 8.4 & 9.8 & 0.547 \\
\hline Atrial fibrillation & 19.0 & 12.9 & 0.062 \\
\hline Heart failure & 3.4 & 4.3 & 0.5 \\
\hline Previous stroke & 18.9 & 16.6 & 0.693 \\
\hline $\begin{array}{l}\text { Axillary temperature at } \\
\text { admission, }{ }^{\circ} \mathrm{C}\end{array}$ & $36.4 \pm 0.6$ & $38.0 \pm 0.4$ & $<0.0001$ \\
\hline $\begin{array}{l}\text { Temperature at admission } \\
- \text { at } 24 \text { hours, }{ }^{\circ} \mathrm{C}\end{array}$ & $0.21 \pm 0.39$ & $0.29 \pm 0.58$ & 0.034 \\
\hline $\begin{array}{l}\text { Decrease in temperature in } \\
24 \text { hours }\end{array}$ & 76.1 & 58.9 & $<0.0001$ \\
\hline Basal glycemia, mg/dL & $137 \pm 47$ & $149.8 \pm 53.1$ & 0.0004 \\
\hline Leukocytes, $\times 10^{3} / \mathrm{mL}$ & $8.5 \pm 3.1$ & $10.6 \pm 3.8$ & $<0.0001$ \\
\hline Platelets, $\times 10^{3} / \mathrm{mL}$ & $203 \pm 77.6$ & $200.5 \pm 90.4$ & 0.920 \\
\hline Fibrinogen, mg/dL & $\begin{array}{l}435.6 \pm \\
100.7\end{array}$ & $475.9 \pm 99.9$ & $<0.0001$ \\
\hline C-reactive protein, $\mathrm{mg} / \mathrm{L}$ & $4.2 \pm 3.9$ & $11.7 \pm 6.9$ & $<0.0001$ \\
\hline Glycosylated hemoglobin & $5.8 \pm 0.9$ & $5.9 \pm 1.0$ & 0.35 \\
\hline LDL cholesterol, mg/dL & $110.9 \pm 35.5$ & $100.1 \pm 31.8$ & 0.014 \\
\hline HDL cholesterol, mg/dL & $39.2 \pm 18.3$ & $35.5 \pm 18.7$ & 0.098 \\
\hline Triglycerides, mg/dL & $103.9 \pm 49.8$ & $112.1 \pm 56.9$ & 0.152 \\
\hline Microalbuminuria, mg/24 h & $15.3 \pm 30.1$ & $27.5 \pm 27.5$ & 0.008 \\
\hline Sedimentation rate, $\mathrm{mm}$ & $22.6 \pm 20.5$ & $46.9 \pm 25.9$ & $<0.0001$ \\
\hline $\begin{array}{l}\text { ICH volume at } \\
\text { admission, } \mathrm{mL}\end{array}$ & $36.9 \pm 37.9$ & $61.2 \pm 54.1$ & $<0.0001$ \\
\hline Growth of the ICH, mL & $11.1 \pm 26.6$ & $5.2 \pm 14.4$ & 0.009 \\
\hline Growth of the ICH $\geq 6 \mathrm{~mL}$ & 39.1 & 25.7 & 0.002 \\
\hline PHHD volume, mL & $11.2 \pm 15.8$ & $21.4 \pm 24.6$ & $<0.0001$ \\
\hline
\end{tabular}

Table 3 Clinical variables, biochemical measures, and neuroimaging values categorized in patients with a negative and positive response to antihyperthermic treatment (continued)

\begin{tabular}{|c|c|c|c|}
\hline & \multicolumn{2}{|c|}{$\begin{array}{l}\text { Antihyperthermic } \\
\text { treatment }\end{array}$} & \multirow[b]{2}{*}{$p$ Value } \\
\hline & No $(n=647)$ & Yes $(n=148)$ & \\
\hline PHHD volume $\geq 6 \mathrm{~mL}$ & 54.1 & 45.9 & 0.083 \\
\hline Leukoaraiosis & 31.3 & 30.7 & 0.927 \\
\hline NIHSS at admission & $12(7,17)$ & $17(13,21)$ & $<0.0001$ \\
\hline $\begin{array}{l}\text { Modified Rankin Scale score } \\
\text { at } 3 \text { months }\end{array}$ & $3(1,6)$ & $6(2,6)$ & $<0.0001$ \\
\hline Good outcome at 3 months & 46.5 & 31.7 & $<0.0001$ \\
\hline ICH topography & & & 0.264 \\
\hline Deep hemisphere & 49.7 & 55.0 & \\
\hline Lobar & 41.8 & 38.2 & \\
\hline Cerebellar & 5.0 & 2.8 & \\
\hline Brainstem & 3.5 & 4.9 & \\
\hline $\begin{array}{l}\text { Hemorrhagic } \\
\text { contamination }\end{array}$ & 20.8 & 24.5 & 0.301 \\
\hline ICH diagnosis & & & $<0.0001$ \\
\hline Hypertensive & 42.6 & 65.0 & \\
\hline Amyloid & 10.7 & 8.6 & \\
\hline Anticoagulants & 15.4 & 7.4 & \\
\hline Other/indeterminate & 31.4 & 19.0 & \\
\hline
\end{tabular}

Abbreviations: $\mathrm{HDL}=$ high-density lipoprotein; $\mathrm{ICH}=$ intracerebral hemorrhage; $L D L=$ low-density lipoprotein; NIHSS = NIH Stroke Scale; PHHD = perihematomal hypodensity.

Values are mean \pm SD or $\%$.

still not safe and has not been proven in clinical trials for patients with $\mathrm{ICH}$.

Based on this evidence, in this study we aimed to investigate the efficacy of a moderate decrease in temperature (in our series, the change in temperature in the first 24 hours, with or without antihyperthermic treatment), since it is incorporated into the clinical practice guidelines for ischemic stroke management. ${ }^{46,47}$ We have verified that a decrease in body temperature multiplied by 11 the association with a good outcome. The variation in body temperature is proportional to the changes in PHHD volume, and this association is independent of other variables.

A questionable aspect of our findings is the limited effectiveness of antihyperthermic treatment, since it only managed to reduce the temperature in fewer than half of the patients who presented an axillary temperature $\geq 37.5^{\circ} \mathrm{C}$ on admission. This is probably due to the multiple mechanisms that can condition the temperature increase in $\mathrm{ICH}$, and the type of hemorrhage is 

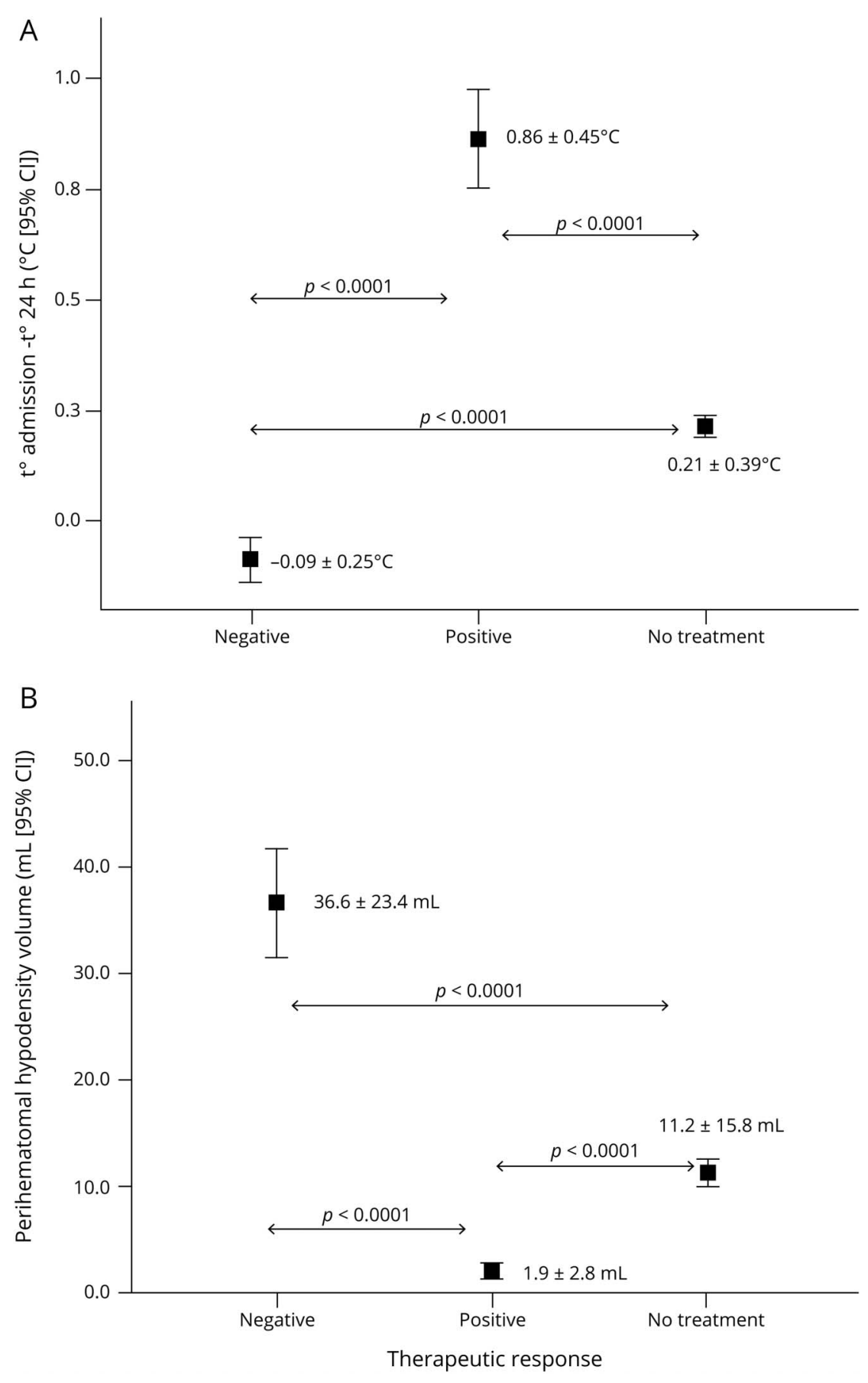

(A) Decrease in body temperature at 24 hours in the antihyperthermic treated group (without and with a therapeutic response) and the nontreated group. (B) Perihematomal hypodensity (PHHD) volume in the 3 groups according to the therapeutic response. $\mathrm{Cl}=$ confidence interval.

undoubtedly one of these variables. ${ }^{13}$ In our series, the therapeutic response was positive in only $31.1 \%$ of hypertensive $\mathrm{ICH}$, in $42.9 \%$ of amyloid $\mathrm{ICH}$, in $25.0 \%$ associated with antiplatelets/anticoagulants, and in $74.2 \%$ of indeterminate cases $(p<0.0001$, data not shown in the Results). The overall benefit (determined as good outcome at 3 months) of patients who received antihyperthermic treatment was $31.8 \%$.

Despite the fact that only $31.8 \%$ of patients who received antihyperthermic treatment benefited from a moderate decrease in temperature, associated with a decrease in PHHD volume (paracetamol and metamizole do not have remarkable antiinflammatory effects raising other mechanisms), these results could encourage the consideration of a prospective and multicentric study, since the design of our study does not allow for the evaluation of a possible benefit of antihyperthermic treatment in normothermic patients.

Our study shows the weakness of its retrospective nature, such as the lack of a blind assignation of patients to 
antihyperthermic treatments that could bias the sample. Nevertheless, the influence of the temperature variation over the different $\mathrm{mRS}$ has the same trend independent on the antihyperthermic treatment. Also, due to the retrospective nature of the study, we could rule out any inclusion bias.

The administration of early antihyperthermic treatment in patients with a spontaneous ICH with a basal axillary temperature $\geq 37.5^{\circ} \mathrm{C}$ is associated with a moderate decrease in temperature in the first 24 hours and with a better prognosis at 3 months in one-third of the treated patients.

\section{Study funding}

This study was partially supported by grants from the Spanish Ministry of Economy and Competitiveness (SAF2014-56336-R and SAF2017-84267-R), Xunta de Galicia (Consellería Educación: GRC2014/027 and IN607A2018/3), Instituto de Salud Carlos III (PIE13/00024 and PI17/01103), Spanish Research Network on Cerebrovascular Diseases RETICS-INVICTUS PLUS (RD16/0019), and by the European Union FEDER program. T. Sobrino (CPII17/00027) and F. Campos (CP14/00154) are recipients of research contracts from the Miguel Servet Program of Instituto de Salud Carlos III. The sponsors did not participate in the study design, collection, analysis, or interpretation of the data, in writing the report, or in the decision to submit the paper for publication.

\section{Disclosure}

The authors report no relevant disclosures. Go to Neurology.org/ $\mathrm{N}$ for full disclosures.

\section{Publication history}

Received by Neurology June 3, 2019. Accepted in final form November 21, 2019.

\section{Appendix Authors}

\begin{tabular}{|c|c|c|}
\hline Name & Location & Contribution \\
\hline $\begin{array}{l}\text { Pablo } \\
\text { Hervella, } \\
\text { PhD }\end{array}$ & $\begin{array}{l}\text { Health Research Institute } \\
\text { of Santiago de Compostela } \\
\text { (IDIS), Santiago de } \\
\text { Compostela, Spain }\end{array}$ & $\begin{array}{l}\text { Designed and } \\
\text { conceptualized the study, } \\
\text { analyzed the data, wrote } \\
\text { the manuscript }\end{array}$ \\
\hline $\begin{array}{l}\text { Manuel } \\
\text { Rodríguez- } \\
\text { Yáñez, MD } \\
\text { PhD }\end{array}$ & $\begin{array}{l}\text { Health Research Institute } \\
\text { of Santiago de Compostela } \\
\text { (IDIS), Santiago de } \\
\text { Compostela, Spain }\end{array}$ & $\begin{array}{l}\text { Major role in the } \\
\text { acquisition of data, } \\
\text { neuroimaging study, } \\
\text { interpreted the data, } \\
\text { revised the manuscript }\end{array}$ \\
\hline $\begin{array}{l}\text { José Manuel } \\
\text { Pumar, MD, } \\
\text { PhD }\end{array}$ & $\begin{array}{l}\text { Clinical University } \\
\text { Hospital, Santiago de } \\
\text { Compostela, Spain }\end{array}$ & $\begin{array}{l}\text { Major role in the } \\
\text { acquisition of data, } \\
\text { neuroimaging study, } \\
\text { interpreted the data, } \\
\text { revised the manuscript }\end{array}$ \\
\hline $\begin{array}{l}\text { Paulo Ávila, } \\
\text { BSc }\end{array}$ & $\begin{array}{l}\text { Health Research Institute } \\
\text { of Santiago de Compostela } \\
\text { (IDIS), Santiago de } \\
\text { Compostela, Spain }\end{array}$ & $\begin{array}{l}\text { Acquired and interpreted } \\
\text { the data, critical revision of } \\
\text { the manuscript }\end{array}$ \\
\hline $\begin{array}{l}\text { Andrés da } \\
\text { Silva- } \\
\text { Candal, PhD }\end{array}$ & $\begin{array}{l}\text { Health Research Institute } \\
\text { of Santiago de Compostela } \\
\text { (IDIS), Santiago de } \\
\text { Compostela, Spain }\end{array}$ & $\begin{array}{l}\text { Acquired and interpreted } \\
\text { the data, critical revision of } \\
\text { the manuscript }\end{array}$ \\
\hline
\end{tabular}

Appendix (continued)

\begin{tabular}{|c|c|c|}
\hline Name & Location & Contribution \\
\hline $\begin{array}{l}\text { Ignacio } \\
\text { López- } \\
\text { Loureiro, } \\
\text { BSc }\end{array}$ & $\begin{array}{l}\text { Health Research Institute } \\
\text { of Santiago de Compostela } \\
\text { (IDIS), Santiago de } \\
\text { Compostela, Spain }\end{array}$ & $\begin{array}{l}\text { Acquired and interpreted } \\
\text { the data, critical revision of } \\
\text { the manuscript }\end{array}$ \\
\hline $\begin{array}{l}\text { Elena } \\
\text { Rodríguez- } \\
\text { Maqueda, } \\
\text { BSc }\end{array}$ & $\begin{array}{l}\text { Health Research Institute } \\
\text { of Santiago de Compostela } \\
\text { (IDIS), Santiago de } \\
\text { Compostela, Spain }\end{array}$ & $\begin{array}{l}\text { Acquired and interpreted } \\
\text { the data, critical revision of } \\
\text { the manuscript }\end{array}$ \\
\hline $\begin{array}{l}\text { Clara } \\
\text { Correa, BSc }\end{array}$ & $\begin{array}{l}\text { Health Research Institute } \\
\text { of Santiago de Compostela } \\
\text { (IDIS), Santiago de } \\
\text { Compostela, Spain }\end{array}$ & $\begin{array}{l}\text { Acquired and interpreted } \\
\text { the data, critical revision of } \\
\text { the manuscript }\end{array}$ \\
\hline $\begin{array}{l}\text { José Castillo, } \\
\text { MD, PhD }\end{array}$ & $\begin{array}{l}\text { Health Research Institute } \\
\text { of Santiago de Compostela } \\
\text { (IDIS), Santiago de } \\
\text { Compostela, Spain }\end{array}$ & $\begin{array}{l}\text { Designed and } \\
\text { conceptualized the study, } \\
\text { analyzed the data, wrote } \\
\text { the manuscript }\end{array}$ \\
\hline $\begin{array}{l}\text { Tomás } \\
\text { Sobrino, } \\
\text { PhD }\end{array}$ & $\begin{array}{l}\text { Health Research Institute } \\
\text { of Santiago de Compostela } \\
\text { (IDIS), Santiago de } \\
\text { Compostela, Spain }\end{array}$ & $\begin{array}{l}\text { Interpreted the data, } \\
\text { critical revision of the } \\
\text { manuscript }\end{array}$ \\
\hline $\begin{array}{l}\text { Francisco } \\
\text { Campos, } \\
\text { PhD }\end{array}$ & $\begin{array}{l}\text { Health Research Institute } \\
\text { of Santiago de Compostela } \\
\text { (IDIS), Santiago de } \\
\text { Compostela, Spain }\end{array}$ & $\begin{array}{l}\text { Interpreted the data, } \\
\text { critical revision of the } \\
\text { manuscript }\end{array}$ \\
\hline $\begin{array}{l}\text { Ramón } \\
\text { Iglesias-Rey, } \\
\text { PhD }\end{array}$ & $\begin{array}{l}\text { Health Research Institute } \\
\text { of Santiago de Compostela } \\
\text { (IDIS), Santiago de } \\
\text { Compostela, Spain }\end{array}$ & $\begin{array}{l}\text { Designed and } \\
\text { conceptualized the study, } \\
\text { analyzed the data, wrote } \\
\text { the manuscript }\end{array}$ \\
\hline
\end{tabular}

\section{References}

1. Feigin VL, Krishnamurtly RV, Parmar P, et al. Update on the global burden of ischemic and hemorrhagic stroke in 1990-2013: the GBD 2013 study. Neuroepidemiology 2015;45:161-176.

2. Rodríguez-Castro E, López-Dequidt I, Santamaría-Cadavid M, et al. Trends in stroke outcomes in the last ten years in a European tertiary hospital. BMC Neurol 2018;18:164.

3. Keep RF, Hua Y, Xi G. Intracerebral haemorrhage: mechanisms of injury and therapeutic targets. Lancet Neurol 2012;11:720-731.

4. Tuhrim S, Horowitz DR, Scacher M, et al. Comparison of model predicting survival following intracerebral hemorrhage. Crit Care Med 1995;23:950-954.

5. Leira R, Dávalos A, Silva Y, et al. Early neurologic deterioration in intracerebral hemorrhage: predictors and associated factors. Neurology 2004;63:461-467.

6. Salman RA, Frantzias J, Lee R, et al. Absolute risk and predictors of the growth of acute spontaneous intracerebral haemorrhage: a systematic review and meta-analysis of individual patient data. Lancet Neurol 2018;17:885-894.

7. Qureshi AI, Mendelow AD, Hanley DF. Intracerebral haemorrhage. Lancet 2009;373: $1632-1644$.

8. Grunwald Z, Beslow LA, Urday S, et al. Perihematomal edema expansion rates and patient outcomes in deep and lobar intracerebral hemorrhage. Neurocrit Care 2017;26:205-212.

9. Wu TY, Sharma G, Strbian D, et al. Natural history of perihematomal edema and impact on outcome after intracerebral hemorrhage. Stroke 2017;48:873-879.

10. Yu Z, Zheng J, You C. Prognostic role of perihematomal edema in intracerebral hemorrhage: a systematic review. Turk Neurosurg 2018;28:511-522.

11. Campos F, Sobrino T, Vietes-Prado A, et al. Hyperthermia in human ischemic and hemorrhagic stroke: similar outcome, different mechanisms. PLoS One 2013;8: e78429.

12. Mehdiratta M, Kumar S, Hackney D, et al. Serum ferritin level and perihematoma edema volume in patients with spontaneous intracerebral hemorrhage. Stroke 2008; 39:1165-1170.

13. Iglesias-Rey, Rodríguez-Yáñez M, Arias $\mathrm{S}$, et al. Inflammation, edema and poor outcome are associated with hyperthermia in hypertensive intracerebral hemorrhage. Eur J Neurol 2018;25:1161-1168.

14. Volbers B, Herrmann S, Willfarth W, et al. Impact of hypothermia and duration on perihemorrhagic edema evolution after intracerebral hemorrhage. Stroke 2016;47: 2249-2255.

15. Leasure A, Kimberly WT, Sansing LH, et al. Treatment of edema associated with intracerebral hemorrhage. Curr Treat Options Neurol 2016;18:9.

16. Kim H, Edwards NJ, Choi HA, et al. Treatment strategies to attenuate perihematomal edema in patients with intracerebral hemorrhage. World Neurosurg 2016;94:32-41. 
17. Melmed KR, Lyden PD. Meta-analysis of pre-clinical trials of therapeutic hypothermia for intracerebral hemorrhage. Ther Hypothermia Temp Manag 2017;7:141-146.

18. Rodríguez-Yáñez M, Castellanos M, Freijo MM, et al. Clinical practice guidelines in intracerebral haemorrhage. Neurología 2013;28:236-249.

19. Broderick J, Connolly S, Feldmann E, et al. Guidelines for the management of spontaneous intracerebral hemorrhage in adults: 2007 update: a guideline from the American Heart Association/American Stroke Association Stroke Council, High Blood Pressure Research Council, and the Quality of Care and Outcomes in Research Interdisciplinary Working Group. Stroke 2007;38:2001-2023.

20. Sims JR, Gharai LR, Sahaefer P, et al. ABC/2 rapid clinical estimate of infarct, perfusion, and mismatch volumes. Neurology 2009;72:2104-2110.

21. Krishnan K, Muktar SF, Lingard J, et al. Performance characteristics of methods for quantifying spontaneous intracerebral haemorrhage: data from the Efficacy of Nitric Oxide in Stroke (ENOS) trial. J Neurol Neurosurg Psychiatry 2015;86:1258-1266.

22. Dowlatshani D, Demchuck AM, Flaherty ML, et al. Defining hematoma expansion in intracerebral hemorrhage: relationship with patient outcome. Neurology 2011;76: 1238-1244.

23. Veltkamp R, Purrucker J. Management of spontaneous intracerebral hemorrhage. Curr Neurol Neurosci Rep 2017;17:80.

24. Kim JY, Bae HJ. Spontaneous intracerebral hemorrhage: management. J Stroke 2017; 19:28-39.

25. Salman RA, Law ZK, Bath PM, et al. Haemostatic therapies for acute spontaneous intracerebral haemorrhage. Cochrane Database Syst Rev 2018;4:CD005951.

26. Gusdon AM, Gialdini G, Kone G, et al. Neutrophil-lymphocyte ratio and perihematomal edema growth in intracerebral hemorrhage. Stroke 2017;48:2589-2592.

27. Urday S, Kimberly WY, Beslow LA, et al. Targeting secondary injury in intracerebral haemorrhage-peri-haematomal oedema. Nat Rev Neurol 2015;11:111-122.

28. Majidi S, Rahim B, Gilani SI, et al. CT evolution of hematoma and surrounding hypodensity in a cadaveric model of intracerebral hemorrhage. J Neuroimaging 2016; 26:346-350.

29. Castillo J, Dávalos A, Álvarez-Sabín J, et al. Molecular signatures of brain injury after intracerebral hemorrhage. Neurology 2002;58:624-629.

30. Buletko AB, Thacker T, Cho SM, et al. Cerebral ischemia and deterioration with lower blood pressure target in intracerebral hemorrhage. Neurology 2018;91:e1058-e1066.

31. Helbok R, Schiefecker AJ, Friberg C, et al. Spreading depolarizations in patients with spontaneous intracerebral hemorrhage: association with perihematomal edema progression. J Cereb Blood Flow Metab 2017;37:1871-1882.

32. $\mathrm{Hu} \mathrm{YL}$, Wang $\mathrm{H}$, Huang $\mathrm{Q}$ et al. MicroRNA-23a-3p promotes the perihematomal edema formation after intracerebral hemorrhage via ZO-1. Eu Rev Med Pharmacol Sci 2018;22:2809-2816.
33. Urday S, Beslow LA, Dai F, et al. Rate of peri-hematomal edema expansion predicts outcome after intracerebral hemorrhage. Crit Care Med 2016;44:790-797.

34. Murthy SB, Moradiya Y, Dawson J, et al. Perihematomal edema and functional outcome in intracerebral hemorrhage: influence of the hematoma volume and location. Stroke 2015;46:3088-3092.

35. Volbers B, Willfarth W, Kuramatsu JB, et al. Impact of perihemorrhagic edema on short-term outcome after intrace4rebral hemorrhage. Neurocrit Care 2016;24 404-412.

36. Yang J, Arima H, Wu G, et al. Prognostic significance of perihematomal edema in acute intracerebral hemorrhage: pooled analysis from the intensive blood pressure reduction in acute cerebral hemorrhage trial studies. Stroke 2015;46: 1009-1013.

37. Poungvarin $\mathrm{N}$, Bhoopat $\mathrm{W}$, Viriyavejakul A, et al. Effects of dexamethasone in primary intracerebral hemorrhage. N Eng J Med 1987;316:1229-1223.

38. Wang X, Arima H, Yang Y, et al. Mannitol and outcome in intracerebral hemorrhage: propensity score and multivariable intensive blood pressure reduction in acute cerebral hemorrhage trial 2 results. Stroke 2015;46:2762-2767.

39. Mehdiratta M, Kumar S, Hackney D, et al. Association between serum ferritin level and perihematomal edema volume in patients with spontaneous intracerebral hemorrhage. Stroke 2008;39:1165-1170.

40. Rincon F, Mayer SA. The epidemiology of intracerebral hemorrhage in the United States from 1979 to 2008. Neurocrit Care 2013;19:95-2008.

41. Lord AS, Gilmon E, Choi HA, et al. Time course and predictors of neurological deterioration after intracerebral hemorrhage. Stroke 2015;46:647-652.

42. Liang $\mathrm{T}, \mathrm{Chen} \mathrm{Q}, \mathrm{Li} \mathrm{Q}$, et al. 5-HTla activation in $\mathrm{PO} / \mathrm{AH}$ area induces therapeutic hypothermia in a rat model of intracerebral hemorrhage. Oncotarget 2017;8: 73613-73626.

43. Kollmn R, Staykov D, Dorfler A, et al. Hypothermia reduces perihemorrhagic edema after intracerebral hemorrhage. Stroke 2010;41:1684-1689.

44. Staykov D, Schwab S, Dorfler A, et al. Hypothermia reduces perihemorrhagic edema after intracerebral hemorrhage: but does it influence function at outcome and mortality? Ther Hypothermia Temp Manag 2011;1:105-106.

45. Staykov D. Mild prolonged hypothermia for large intracerebral hemorrhage. Neurocrit Care 2013;18:178-183.

46. Powerr WJ, Derdeyn CP, Biller J, et al. 2015 American Heart Association/American Stroke Association focused update on the 2013 guidelines for the early management of patients with acute ischemic stroke regarding endovascular treatment: a guideline for healthcare professionals from the American Heart Association/American Stroke Association. Stroke 2015;46:3020-3035.

47. Alonso M, Egido JA, Casado I, et al. Guía para el tratamiento del infarto cerebral agudo. Neurología 2014;29:102-122. 


\section{Neurology}

Antihyperthermic treatment decreases perihematomal hypodensity

Pablo Hervella, Manuel Rodríguez-Yáñez, José Manuel Pumar, et al.

Neurology 2020;94;e1738-e1748 Published Online before print March 27, 2020

DOI 10.1212/WNL.0000000000009288

This information is current as of March 27, 2020

\section{Updated Information \&} Services

References

Citations

Subspecialty Collections

Permissions \& Licensing

Reprints including high resolution figures, can be found at: http://n.neurology.org/content/94/16/e1738.full

This article cites 47 articles, 18 of which you can access for free at: http://n.neurology.org/content/94/16/e1738.full\#ref-list-1

This article has been cited by 1 HighWire-hosted articles: http://n.neurology.org/content/94/16/e1738.full\#\#otherarticles

This article, along with others on similar topics, appears in the following collection(s):

\section{Infarction}

http://n.neurology.org/cgi/collection/infarction

Intracerebral hemorrhage

http://n.neurology.org/cgi/collection/intracerebral_hemorrhage

Outcome research

http://n.neurology.org/cgi/collection/outcome_research

Prognosis

http://n.neurology.org/cgi/collection/prognosis

Information about reproducing this article in parts (figures,tables) or in its entirety can be found online at:

http://www.neurology.org/about/about_the_journal\#permissions

Information about ordering reprints can be found online:

http://n.neurology.org/subscribers/advertise

Neurology ${ }^{\circledR}$ is the official journal of the American Academy of Neurology. Published continuously since 1951 , it is now a weekly with 48 issues per year. Copyright Copyright (C) 2020 The Author(s). Published by Wolters Kluwer Health, Inc. on behalf of the American Academy of Neurology.. All rights reserved. Print ISSN: 0028-3878. Online ISSN: 1526-632X.

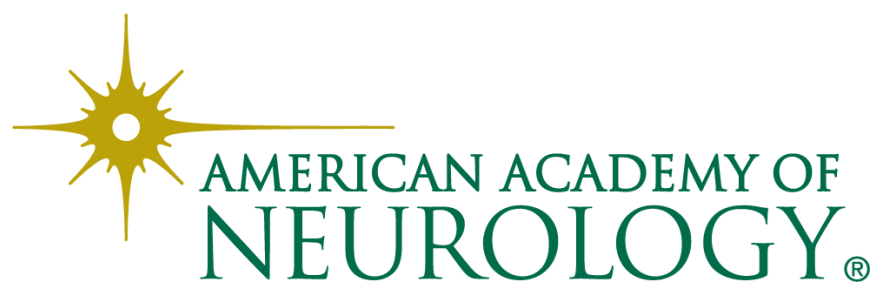

